\title{
Race Composition of Puccinia striiformis f. sp. tritici in Tibet, China
}

\author{
Xiaoping Hu, Jiaojiao Li, Yating Wang, Baotong Wang, Qiang Li, and Zhensheng Kang, State Key Laboratory of Crop Stress Biol- \\ ogy in Arid Areas, College of Plant Protection, Northwest A\&F University, Yangling 712100, China; Minna Yang and Yueling Peng, \\ Tibet Agricultural and Animal Husbandry College, Linzhi 860000, China; Taiguo Liu and Wanquan Chen, State Key Laboratory for \\ the Biology of Plant Diseases and Insect Pests, Institute of Plant Protection, Chinese Academy of Agricultural Science, Beijing 100193, \\ China; and Xiangming Xu, State Key Laboratory of Crop Stress Biology in Arid Areas, College of Plant Protection, Northwest A\&F \\ University, China, and East Malling Research, West Malling, Kent Me19 6BJ, UK
}

\begin{abstract}
Hu, X., Li, J., Wang, Y., Wang, B., Li, Q., Kang, Z., Yang, M., Peng, Y., Liu, T., Chen, W., and Xu, X. 2012. Race composition of Puccinia striiformis f. sp. tritici in Tibet, China. Plant Dis. 96:1615-1620.

In Tibet, China, wheat stripe rust (caused by Puccinia striiformis f. sp. tritici) has recently become one of the most destructive diseases on winter wheat. To identify races of the pathogen in Tibet, 261 isolates were obtained in 2010 and tested on seedlings of a standard set of 19 wheat indicator genotypes. Of the 261 isolates, 248 were identified as members of 19 known races (CYR17, CYR20, CYR21, CYR22, CYR23, CYR29, CYR31, CYR32, CYR33, Lov13-6, Su11-1, Su11-2, Su11-3, Su11-4, Su11-5, Su11-6, Su11-7, Su11-8, and Su11-13), and

13 identified as representatives of 4 new races. CYR32 and CYR33 were the most predominant. The number of races and their frequencies in Tibet were more similar to the fungal populations in Sichuan and Gansu provinces than to those in Yunnan, Qinghai, and Shaanxi provinces. The results suggest that Tibet is also a possible center of inoculum source and genetic variation for the stripe rust pathogen in addition to Sichuan and Gansu.
\end{abstract}

Wheat stripe rust (yellow rust), caused by Puccinia striiformis $\mathrm{f}$. sp. tritici Erikss., is one of most destructive diseases in many wheat-growing regions worldwide $(2,6,11,20,21)$, including China $(2,4,5)$. It was estimated that severe rust epidemics in China caused yield losses of $6.00,3.20,2.65$, and 1.40 million metric tons in 1950, 1964, 1990, and 2002, respectively $(5,12)$.

Host resistance genes have been deployed to manage stripe rust in China but are often overcome by the pathogen. New races capable of overcoming single-gene conferred resistance often render corresponding resistance genes ineffective within 5 years of deployment in commercial wheat cultivars $(3,14,15)$. Since the 1950s, wheat cultivars have been changed eight times on a large scale in order to keep up with the pace of emergence of new $P$. striiformis $\mathrm{f}$. sp. tritici races. In recent years, resistance to $P$. striiformis f. sp. tritici in more than $95 \%$ of Chinese cultivars has been overcome (13). Understanding the pathogen race composition in time and space is important for breeding cultivars with effective resistance genes $(2,7,10,14,15)$. The Chinese National Wheat Rust Collaborative Group (CNWRCG) has been monitoring P. striiformis $\mathrm{f}$. sp. tritici races since 1957. To date, 33 Chinese yellow rust (CYR) races have been named; in addition, there are more than 40 unnamed races that have already been identified (1).

Tibet Autonomous Region is situated in the southwest of China bordering Sichuan, Yunnan, Qinghai, and Xinjiang provinces (Fig. 1) and also India, Burma, Bhutan, and Nepal. The average altitude of Tibet is over $4,000 \mathrm{~m}$. Wheat is the second most important food crop in Tibet, second only to barley. Winter wheat accounted for nearly $77 \%$ (28,000 hectares) in 2010, primarily in Lasha, Shannan, Linzhi, Rikeze, and Changdu regions (Fig. 1). Wheat-growing areas in Tibet can be classified into three cropping zones. The first zone consists of the winter wheat areas in low-elevation valleys in the southeast of Tibet, including Caou, Caya, Basu, Mangkang,

Corresponding authors: B. Wang, E-mail: wangbt@nwsuaf.edu.cn; and X. Xu, E-mail: Xiangming.Xu@emr.ac.uk

Accepted for publication 21 May 2012.

http://dx.doi.org/10.1094/PDIS-10-11-0884-RE

(C) 2012 The American Phytopathological Society
Bomi, Linzhi, Milin, and Yadong counties. These areas are located in the warm and humid plateau, with an average altitude below $3,000 \mathrm{~m}$ and minimum temperatures usually above $-2^{\circ} \mathrm{C}$. The second zone covers the winter and spring wheat areas in the cool and semiarid plateau, with altitudes between 3,000 and $4,000 \mathrm{~m}$, including the Changdu, Lasa, Shannan, and Rikeze regions. The third zone consists of the spring wheat areas in the cold and wet or semiarid plateaus of northwestern and southwestern Tibet, with altitudes over $4,000 \mathrm{~m}$. Wheat stripe rust mainly occurs on winter wheat in the first two zones, where the climatic conditions are generally conducive to stripe rust development and enable the pathogen to complete its life cycle (17). Because susceptible cultivars have been grown during the last decade in Tibet, wheat stripe rust has gradually become a limiting factor for winter wheat production, particularly in Linzhi. Information on $P$. striiformis f. sp. tritici races in Tibet is limited, hampering effective deployment of resistant cultivars.

To fill this knowledge gap on $P$. striiformis $\mathrm{f}$. sp. tritici races in Tibet, we have collected 376 P. striiformis f. sp. tritici samples from Tibet and identified races using a standard set of wheat genotypes that have been used to differentiate $P$. striiformis $\mathrm{f}$. sp. tritici races in China (1). Frequencies of $P$. striiformis f. sp. tritici races in Tibet were compared with those from other major stripe rust epidemic areas in China, including Sichuan, Yunnan, Qinghai, Gansu, and Shaanxi provinces (9). This information on race composition is valuable for understanding pathogen dispersal among different regions, and for breeding and deploying resistant cultivars to manage wheat stripe rust in Tibet and other provinces.

\section{Materials and Methods}

Collecting stripe rust samples. In total, 376 P. striiformis $\mathrm{f}$. sp. tritici samples were randomly collected from adult plants in Miling, Lingzhi, Gongbujiangda, and Bomi counties in Lingzhi, Tibet in June 2010 (Table 1; Fig. 1). Leaves with sporulating stripe rust lesions were kept in an envelope inside a desiccator at room temperature for a maximum of 7 days before inoculum multiplication.

Multiplying urediniospores. Leaf samples were incubated on water-soaked tissue paper in petri dishes in the dark at $4^{\circ} \mathrm{C}$ for 15 to $18 \mathrm{~h}$ to produce fresh urediniospores, which were used to inoculate seedlings of susceptible 'Mingxian 169' to multiply inoculum. Seed were sown in pots of $10 \mathrm{~cm}$ in diameter containing cow dung compost and soil. Ten days after sowing, seedlings with two leaves 
were inoculated with fresh urediniospores of a single isolate using a spatula. A single urediniospore was obtained with a needle under $\times 200$ magnification (BX51 Olympus microscope). Immediately after inoculation, the seedlings were kept in a dew chamber at $10^{\circ} \mathrm{C}$ for $24 \mathrm{~h}$ and then placed on greenhouse benches with temperatures of 14 to $17^{\circ} \mathrm{C}$ and a photoperiod of 10 to $14 \mathrm{~h}$. The plants were covered with a transparent plastic cylinder to prevent cross contamination. Fresh urediniospores produced on these inoculated seedlings were then collected, vacuum dried, and kept at $-80^{\circ} \mathrm{C}$ until used to test on differential cultivars.

Differential genotypes. The 19 standard wheat genotypes (1) were used to differentiate $P$. striiformis f. sp. tritici races. These (together with their corresponding resistance genes) are Trigo Eureka (Yr6), Fulhard (unknown), Lutescenes 128 (unknown), Mentana (unknown), Virgilio (YrVir1, YrVir2), Abbondanza (unknown), Early Piemium (unknown), Funo ( $Y r A$, other unknown), Danish (Yr3), Jubilejina (YrJu1, YrJu2, YrJu3, YrJu4), Fengchan 3 (Yrl), Lovrin 13 (Yr9, other unknown), Kangyin 655 (Yrl, YrKyl, YrKy2), Suwon11 (YrSu), Zhong 4 (unknown), Lovrin 10 (Yr9), Hybrid46 (Yr3b, Yr4b), Triticum spelta album (Yr5), and Guinong 22 (unknown).

Identifying races. The standard protocol as previously described $(1,12)$ was used to determine races for the isolates. If the test data suggested that an isolate was composed of more than one race, spores were collected from one or more differential genotypes to obtain subisolates; these subisolates were then tested again on the 19 differential genotypes. Sometimes, several cycles of subisolating and testing were necessary to assign a relatively pure subisolate for identifying it to a single race.

Determination of races was based on the infection type (IT) recorded 15 to 20 days after inoculation on a scale of 0 to 9 (8). An isolate was considered avirulent on a particular genotype when its IT score was in the range of 0 to 6 (0: no visible symptoms; 1 : necrotic flecks; 2: necrotic areas without sporulation; 3: necrotic and chlorotic areas with restricted sporulation; 4-6: moderate uredinia with necrosis and chlorosis). Otherwise, an isolate was classified as virulent; that is, resulting in production of abundant uredia with chlorosis (IT 7 and 8) or without chlorosis (IT 9). All experiments were carried out in Shaanxi Taibai Key Field Observation Experimental Station of Wheat Stripe Rust, the Ministry of Agriculture, China.

The frequencies of $P$. striiformis $\mathrm{f}$. sp. tritici races in Tibet were compared with those in other major stripe rust epidemic provinces of China (Gansu, Qinghai, Yunnan, Sichuan, and Shaanxi) in 2010 (9)m and $\chi^{2}$ tests based on the maximum likelihood test were used to determine whether the frequencies of virulences against major resistance genes differed among the six regions (Gansu, Qinghai, Yunnan, Sichuan, Shaanxi, and Tibet).

\section{Results}

Of the 376 samples collected from Miling, Linzhi, Gongbujiangda, and Bomi, 261 isolates were recovered and identified for their respective $P$. striiformis f. sp. tritici races. In total, 248 of the 261 isolates were identified as 19 previously reported races (Table 2). Among them, CYR32 (31.8\%) and CYR33 (24.1\%) were the most prevalent races, whereas the other 17 races had frequencies less than $7 \%$. The other 13 isolates were identified as four new races that differed in their virulence on four differential genotypes (Mentana, Early Premium, Fengchan 3, and Suwon11; Table 2).

More races of the early-CYR series (prior to CYR28) were detected in Tibet than in other major provinces (Table 3), except in Gansu. CYR17, CYR20, CYR21, and CYR23 were detected in

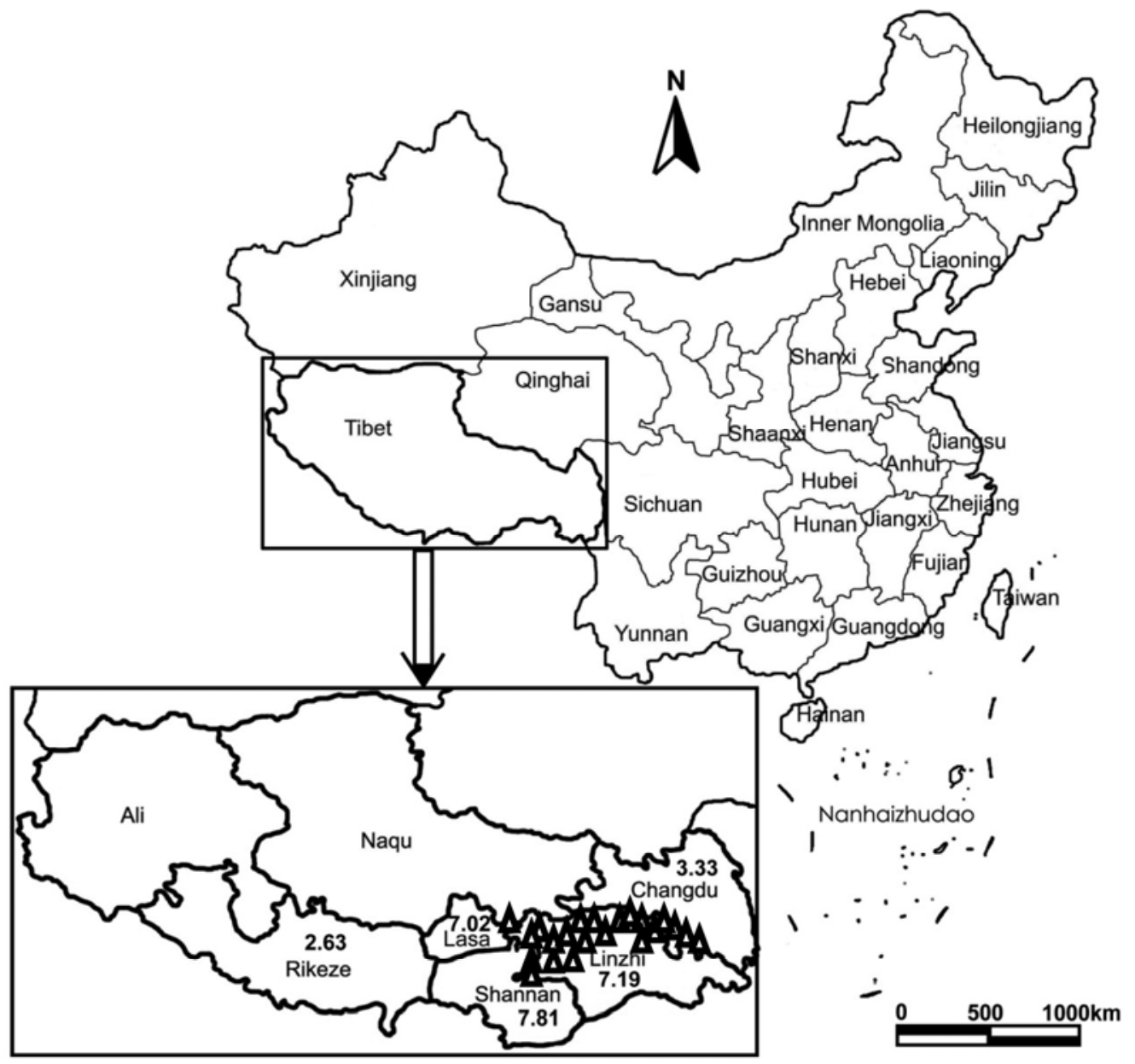

Fig. 1. Winter-wheat-growing areas in Tibet in 2010. Open triangles represents sites that were sampled for Puccinia striiformis f. $\mathrm{sp}$. tritici in 2010. Number next to the site name is the winter wheat area (in thousand hectares) in the corresponding locations. 
both Tibet and Gansu; the frequency of these races in Gansu was lower than in Tibet (Table 3). Fewer races were detected in Qinghai and Yunnan than in the other four provinces, possibly due to fewer samples (Table 3). Although Spearman's rank correlation indicated that prevalent races were similar in most sampled regions, the race composition in Tibet was similar to only those of Sichuan and Gansu $(P<0.05)$ based on Lin's concordance correlation coefficient. CYR32 and CYR33 were the most common races in Tibet, Gansu, and Shaanxi (Table 3). Only races CYR32 and CYR31 in the Hybrid 46 group were found in Tibet, which was similar to
Qinghai. In contrast, more races were found in the Hybrid 46 group in other regions (Table 3). More races in Suwon 11 group were found in Tibet, Sichuan, Gansu, and Shaanxi than in Qinghai and Yunan. Overall, relative frequencies of races in the five groups differed significantly among the six provinces $(P<0.001$; Fig. 2$)$. Races in Tibet, Sichuan, and Shaanxi were dominated by races in the Hybrid 46 and Suwon 11 groups whereas, in Gansu, races in the Suwon 11 and others groups dominated.

The overall frequencies of virulence types against $\mathrm{Yrl}$ (Fengchan 3), $\operatorname{Yr} 3$ (Danish 1), and $\mathrm{YrA}$ (Funo) were similar across

Table 1. Information on the sites in Tibet from which wheat leaves with stripe rust lesions were sampled in 2010

\begin{tabular}{|c|c|c|c|c|c|}
\hline Site & Latitude and longitude & $\begin{array}{l}\text { Elevation } \\
\text { (m) }\end{array}$ & $\begin{array}{l}\text { Severity } \\
(\%)^{\mathrm{a}}\end{array}$ & $\begin{array}{c}\text { Incidence } \\
(\%)^{\mathbf{b}}\end{array}$ & $\begin{array}{c}\text { Number } \\
\text { of samples }\end{array}$ \\
\hline Dongru village, Bayi town, Linzhi county & $\mathrm{N} 29^{\circ} 38^{\prime} 12.0^{\prime \prime} \mathrm{E} 94^{\circ} 20^{\prime} 53.6^{\prime \prime}$ & 3,000 & $20-30$ & 100 & 10 \\
\hline Jiemai village, Bayi town, Linzhi county & $\mathrm{N} 29^{\circ} 34^{\prime} 15.5^{\prime \prime} \mathrm{E} 94^{\circ} 25^{\prime} 19.4^{\prime \prime}$ & 2,962 & $15-20$ & 85 & 16 \\
\hline Bujiu town, Linzhi county & $\mathrm{N} 29^{\circ} 28^{\prime} 40.1^{\prime \prime} \mathrm{E} 94^{\circ} 25^{\prime} 1.5^{\prime \prime}$ & 2,943 & $20-30$ & 100 & 17 \\
\hline Bangna village, Bujiu town, Linzhi county & $\mathrm{N} 29^{\circ} 28^{\prime} 30.8^{\prime \prime} \mathrm{E} 94^{\circ} 26^{\prime} 41.4^{\prime \prime}$ & 2,943 & $10-50$ & 100 & 15 \\
\hline Meeting rivers, Linzhi county & $\mathrm{N} 29^{\circ} 25^{\prime} 59.1^{\prime \prime} \mathrm{E} 94^{\circ} 27^{\prime} 9.6^{\prime \prime}$ & 2,938 & $10-20$ & 75 & 13 \\
\hline Gengzhang villiage, Linzhi county & $\mathrm{N} 29^{\circ} 45^{\prime} 17.1^{\prime \prime} \mathrm{E} 94^{\circ} 1^{\prime} 50.3^{\prime \prime}$ & 3,102 & $10-20$ & 100 & 21 \\
\hline Baiba villiage, Linzhi county & $\mathrm{N} 29^{\circ} 48^{\prime} 18.0^{\prime \prime} \mathrm{E} 93^{\circ} 48^{\prime} 1^{\prime \prime}$ & 3,174 & 5 & 1 & 6 \\
\hline Gangga village, Milin county & $\mathrm{N} 29^{\circ} 16^{\prime} 47.6^{\prime \prime} \mathrm{E} 94^{\circ} 18^{\prime} 45.4^{\prime \prime}$ & 2,934 & $5-15$ & 80 & 32 \\
\hline Near airport, Langduo town, Milin county & $\mathrm{N} 29^{\circ} 21^{\prime} 46.2^{\prime \prime} \mathrm{E} 94^{\circ} 26^{\prime} 1.6^{\prime \prime}$ & 2,931 & $20-30$ & 100 & 20 \\
\hline Milin village, Nanyiluoba town, Milin county & $\mathrm{N} 29^{\circ} 11^{\prime} 20.3^{\prime \prime} \mathrm{E} 94^{\circ} 10^{\prime} 41.9^{\prime \prime}$ & 2,960 & $10-20$ & 100 & 29 \\
\hline Mini village, Qiangna town, Milin county & $\mathrm{N} 29^{\circ} 22.7^{\prime} 10.7^{\prime \prime} \mathrm{E} 94^{\circ} 33^{\prime} 59.7^{\prime \prime}$ & 2,936 & $20-30$ & 100 & 28 \\
\hline Langga village, Danniang town, Milin county & $\mathrm{N} 29^{\circ} 26^{\prime} 36.6^{\prime \prime} \mathrm{E} 94^{\circ} 42^{\prime} 11.1^{\prime \prime}$ & 2,960 & $10-20$ & 70 & 27 \\
\hline Bahe village, Gongbujiangda county & $\mathrm{N} 29^{\circ} 54^{\prime} 21.8^{\prime \prime} \mathrm{E} 93^{\circ} 36^{\prime} 45.8^{\prime \prime}$ & 3,249 & 5 & 1 & 8 \\
\hline Longya village, Zamu town, Bomi county & $\mathrm{N} 29^{\circ} 45^{\prime} 32.8^{\prime \prime} \mathrm{E} 95^{\circ} 58^{\prime} 5.3^{\prime \prime}$ & 3,074 & $10-30$ & 70 & 19 \\
\hline Gala village, Sunzong town, Bomi county & $\mathrm{N} 29^{\circ} 48^{\prime} 37.7^{\prime \prime} \mathrm{E} 95^{\circ} 48^{\prime} 14.8^{\prime \prime}$ & 2,812 & $30-50$ & 85 & 22 \\
\hline Genni village, Sunzong town, Bomi county & $\mathrm{N} 29^{\circ} 44^{\prime} 47.7^{\prime \prime} \mathrm{E} 96^{\circ} 5^{\prime} 7.5^{\prime \prime}$ & 3,046 & $30-70$ & 100 & 18 \\
\hline Kada village, Palongzangbu, Bomi county & $\mathrm{N} 29^{\circ} 54^{\prime} 10.5^{\prime \prime} \mathrm{E} 95^{\circ} 38^{\prime} 46.6^{\prime \prime}$ & 2,720 & $20-50$ & 60 & 13 \\
\hline Zhongsha village, Gu town, Bomi county & $\mathrm{N} 29^{\circ} 54^{\prime} 38.3^{\prime \prime} \mathrm{E} 95^{\circ} 29^{\prime} 9.2^{\prime \prime}$ & 2,648 & $5-10$ & 30 & 7 \\
\hline Suotong village, Gu town, Bomi county & $\mathrm{N} 29^{\circ} 59^{\prime} 49.1^{\prime \prime} \mathrm{E} 95^{\circ} 18^{\prime} 32.5^{\prime \prime}$ & 2,448 & $20-50$ & 80 & 19 \\
\hline Zibu village, Gu town, Bomi county & $\mathrm{N} 29^{\circ} 33^{\prime} 27.2^{\prime \prime} \mathrm{E} 94^{\circ} 30^{\prime} 4.1^{\prime \prime}$ & 3,190 & 5 & 10 & 9 \\
\hline Mirui town, Linzhi county & $\mathrm{N} 29^{\circ} 29^{\prime} 35.7^{\prime \prime} \mathrm{E} 96^{\circ} 36^{\prime} 38.6^{\prime \prime}$ & 3,086 & $30-50$ & 70 & 14 \\
\hline Zhamu town, Bomi county & $\mathrm{N} 29^{\circ} 50^{\prime} 35.4^{\prime \prime} \mathrm{E} 95^{\circ} 46^{\prime} 42.7^{\prime \prime}$ & 2,755 & $10-20$ & 40 & 13 \\
\hline
\end{tabular}

a Percentage of leaf area with uredia.

b Percentage of diseased plants.

Table 2. Races of Puccinia striiformis f. sp. tritici and their first year of detection, frequency in 2010 in Tibet, and virulence and avirulence on 19 Chinese differential genotypes

\begin{tabular}{|c|c|c|c|c|c|c|c|c|c|c|c|c|c|c|c|c|c|c|c|c|c|}
\hline \multirow[b]{2}{*}{ Race $^{\mathbf{b}}$} & \multirow[b]{2}{*}{ Year $^{\mathrm{c}}$} & \multirow[b]{2}{*}{$2010(\%)$} & \multicolumn{19}{|c|}{ Virulence (V) and avirulence (A) of races on differential genotype ${ }^{a}$} \\
\hline & & & 1 & 2 & 3 & 4 & 5 & 6 & 7 & 8 & 9 & 10 & 11 & 12 & 13 & 14 & 15 & 16 & 17 & 18 & 19 \\
\hline CYR17 & 1965 & 4.60 & VA & $\mathrm{V}$ & $\mathrm{A}$ & VA & A & VA & V & A & A & A & $\mathrm{AV}$ & $\mathrm{A}$ & A & A & A & A & A & A & A \\
\hline CYR20 & 1968 & 4.60 & AV & V & $\mathrm{AV}$ & $\mathrm{AV}$ & A & A & A & $\mathrm{V}$ & A & A & $\mathrm{V}$ & A & A & $\mathrm{A}$ & A & A & $\mathrm{A}$ & $\mathrm{A}$ & A \\
\hline CYR21 & 1975 & 0.77 & VA & V & $\mathrm{V}$ & VA & $\mathrm{A}$ & V & V & VA & VA & V & V & A & A & A & A & A & A & A & A \\
\hline CYR22 & 1975 & 0.38 & $\mathrm{~V}$ & $\mathrm{~V}$ & $\mathrm{~V}$ & VA & A & $\mathrm{V}$ & $\mathrm{V}$ & $\mathrm{V}$ & VA & V & V & $\mathrm{A}$ & V & A & $\mathrm{A}$ & A & A & A & A \\
\hline CYR23 & 1978 & 3.83 & V & $\mathrm{V}$ & $\mathrm{V}$ & $\mathrm{V}$ & A & $\mathrm{V}$ & V & $\mathrm{V}$ & $\mathrm{V}$ & A & V & A & A & A & A & A & A & A & A \\
\hline CYR29 & 1985 & 1.15 & $\mathrm{~V}$ & V & $\mathrm{V}$ & V & $\mathrm{V}$ & $\mathrm{V}$ & V & $\mathrm{V}$ & $\mathrm{V}$ & A & V & V & A & A & A & V & A & $\mathrm{A}$ & A \\
\hline CYR31 & 1993 & 5.36 & V & V & V & V & V & V & V & V & V & A & V & V & A & V & A & V & V & A & A \\
\hline CYR32 & 1994 & 31.80 & $\mathrm{~V}$ & V & $\mathrm{V}$ & V & $\mathrm{V}$ & $\mathrm{V}$ & V & V & V & V & V & V & V & V & A & V & $\mathrm{V}$ & A & A \\
\hline CYR33 & 1997 & 24.14 & AV & V & $\mathrm{V}$ & V & VA & V & V & $\mathrm{V}$ & $\mathrm{V}$ & V & V & V & V & V & A & V & A & A & A \\
\hline Lov13-6 & 1987 & 0.38 & VA & $\mathrm{V}$ & V & V & $\mathrm{V}$ & $\mathrm{V}$ & V & VA & VA & A & V & A & A & V & A & V & A & A & A \\
\hline Su11-1 & 1982 & 4.60 & $\mathrm{~V}$ & $\mathrm{~V}$ & A & A & A & A & V & A & $\mathrm{A}$ & A & A & A & A & V & A & A & A & A & A \\
\hline Su11-2 & 1985 & 0.38 & V & $\mathrm{V}$ & $\mathrm{V}$ & V & $\mathrm{V}$ & $\mathrm{V}$ & V & $\mathrm{V}$ & V & A & V & A & A & V & A & A & A & A & A \\
\hline Su11-3 & 1993 & 0.38 & VA & V & $\mathrm{V}$ & V & $\mathrm{V}$ & V & V & V & V & V & V & A & V & V & A & A & A & A & A \\
\hline Su11-4 & 1995 & 1.92 & AV & $\mathrm{V}$ & $\mathrm{V}$ & $\mathrm{V}$ & $\mathrm{A}$ & V & V & $\mathrm{V}$ & V & $\mathrm{V}$ & V & A & V & V & A & V & A & A & A \\
\hline Su11-5 & 1995 & 2.30 & $\mathrm{~V}$ & $\mathrm{~V}$ & V & $\mathrm{V}$ & VA & V & V & V & V & AV & V & A & A & V & A & V & $\mathrm{A}$ & A & A \\
\hline Su11-6 & 1995 & 6.90 & $\mathrm{~V}$ & $\mathrm{~V}$ & $\mathrm{~V}$ & $\mathrm{AV}$ & A & $\mathrm{V}$ & V & $\mathrm{V}$ & V & V & A & V & A & V & A & A & $\mathrm{A}$ & A & A \\
\hline Su11-7 & 1995 & 0.38 & V & $\mathrm{V}$ & $\mathrm{V}$ & $\mathrm{V}$ & VA & V & V & V & V & A & V & V & A & V & A & V & $\mathrm{A}$ & A & A \\
\hline Su11-8 & 1996 & 0.38 & V & V & V & V & A & V & V & V & V & A & V & A & A & $\mathrm{V}$ & A & A & A & A & A \\
\hline Su11-13 & 1997 & 0.77 & $\mathrm{~V}$ & $\mathrm{~V}$ & $\mathrm{~V}$ & $\mathrm{~V}$ & A & V & V & V & V & V & $\mathrm{V}$ & A & A & $\mathrm{V}$ & A & A & A & A & A \\
\hline Unnamed & 2010 & 0.38 & A & V & A & $\mathrm{A}$ & $\mathrm{A}$ & A & $\mathrm{V}$ & A & A & A & V & A & A & A & A & A & A & A & A \\
\hline Unnamed & 2010 & 3.83 & A & $\mathrm{V}$ & A & A & A & A & V & A & A & A & A & A & A & A & A & A & A & A & A \\
\hline Unnamed & 2010 & 0.83 & A & V & A & V & $\mathrm{A}$ & A & V & A & A & A & A & A & A & A & A & A & A & A & A \\
\hline Unnamed & 2010 & 0.38 & A & $\mathrm{V}$ & A & A & A & A & A & A & A & A & A & A & A & V & A & A & A & A & A \\
\hline
\end{tabular}

${ }^{a}$ Chinese differential genotypes: $1=$ Trigo Eureka, $2=$ Fulhard, $3=$ Lutescens $128,4=$ Mentana, $5=$ Virgilio, $6=$ Abbondanza, $7=$ Early Premium, 8 = Funo, $9=$ Danish 1, $10=$ Jubilejina 2, $11=$ Fengchan 3, $12=$ Lovrin 13, $13=$ Kangyin 655, $14=$ Suwon 11, $15=$ Zhong 4, $16=$ Lovrin 10, $17=$ Hybrid 46, $18=$ Triticum spelta album, and $19=$ Guinong $22 . \mathrm{V}=$ virulent, $\mathrm{A}=$ avirulent, $\mathrm{AV}=$ avirulence area $>$ virulence area, and VA = virulence area $>$ avirulence area.

b CYR: Chinese yellow rust; Lov13-X and Su11-X: different "pathotypes" within the race groups virulent on Lovrin 13 and Suwon 11 , respectively.

c Year first detected. 
the six regions, all close to $100 \%$. The frequencies of virulence types against $\operatorname{Yr} 6$ (Trigo Eureka), $\operatorname{Yr} 9$ (Lovrin10 and Lovrin13), and $\mathrm{Yr} 3 \mathrm{~b} / 4 b$ (Hybrid 46) varied greatly among regions, ranging from $49.3 \%$ in Shaanxi to $100 \%$ in Qinghai, from $26.7 \%$ in Yunnan to $100 \%$ in Qinghai, and from $27.9 \%$ in Qinghai to $73.3 \%$ in Yunnan, respectively. Relative frequency of virulence against $\operatorname{Yrl}, \mathrm{Yr} 3$, and $Y r A$ did not significantly vary among the six regions $(P>$ $0.05)$ but relative frequency of virulence against $\operatorname{Yr} 6, \operatorname{Yr} 9$, and $Y r 3 b / 4 b$ significantly varied among the six provinces $(P<0.001$; Table 4).

\section{Discussion}

Wheat strip rust has caused huge yield losses about once every decade in China since 1940s (5). Resistance to stripe rust in major wheat cultivars has been regularly circumvented. In China, major resistance genes such as $Y r 1, Y r 3$, and $Y r A$ appear to be almost completely overcome by all tested $P$. striiformis f. sp. tritici isolates. This present survey study suggested that other genes such as $\operatorname{Yr} 6$ and $Y r 9$ were ineffective against considerable proportions of tested isolates in major wheat-growing areas. Thus, these genes should not all be used in breeding programs.

To monitor the dynamics of $P$. striiformis f. sp. tritici races, the CNWRCG has been continuously updating differential genotypes to differentiate $P$. striiformis f. sp. tritici races. However, most wheatgrowing areas in Tibet have not been covered by the CNWRCG annual survey. Previous studies of wheat stripe rust in Tibet focused on understanding epidemic development (16) and pathogenicity differences among $P$. striiformis f. sp. tritici isolates $(18,19)$.

For the first time, we obtained comprehensive information of the identity and composition of $P$. striiformis $\mathrm{f}$. sp. tritici races in Tibet in the present study. The number of races detected in Tibet is comparable with those in Sichuan and Gansu, which have been considered as the major sources of inoculum and virulence variation because new $P$. striiformis f. sp. tritici races usually first emerged in these two regions and then gradually spread to other regions $(5,22)$. Direct and indirect dispersal of $P$. striiformis $\mathrm{f}$. sp. tritici races from Gansu to Tibet is unlikely because Qinghai province lies between Gansu and Tibet and fewer $P$. striiformis $\mathrm{f}$. sp. tritici races were observed in Qinghai. Frequent one-way or two-way exchange of $P$. striiformis f. sp. tritici urediniospores between Sichuan and Tibet is more likely. Another possibility is that Tibet itself is also a center of $P$. striiformis f. sp. tritici sources because $P$. striiformis f. $\mathrm{sp}$. tritici can oversummer and overwinter in southeastern Tibet, hence completing its annual life cycle as in Sichuan and Gansu (17). This is supported by the fact that several new races were detected in Tibet. The P. striiformis $\mathrm{f}$. sp. tritici population in Tibet might be related to the populations in the neighboring countries such as India and Nepal, although this is unlikely given the Himalaya mountain range between the regions.

Race structure of a pathogen population depends largely upon the composition of resistant genes deployed in the region. Given the great number of $P$. striiformis f. sp. tritici races, surprisingly, there are only four major wheat cultivars that have been grown for many years in Tibet, which is in contrast to the number of cultivars in other provinces (Sichuan $=14$, Yunnan $=19$, Gansu $=29$, Shaanxi $=14$, and Qinghai $=8$ ). This could be due to the complex genetic background regarding resistance to $P$. striiformis f. $\mathrm{sp}$. tritici in the four cultivars grown in Tibet (Zangdong 10, Zangdong 20, Shandong 6, and Feimai), which are not currently grown in other regions. It is also possible that the isolates collected from

Table 3. Comparison of frequencies of Puccinia striiformis f. sp. tritici races in 2010 among the six regions in central western China

\begin{tabular}{|c|c|c|c|c|c|c|c|}
\hline \multirow[b]{2}{*}{ Races } & \multicolumn{6}{|c|}{ Provinces (region) } & \multirow[b]{2}{*}{ Average } \\
\hline & Tibet & Sichuan & Qinghai & Yunnan & Gansu & Shaanxi & \\
\hline CYR17 & 4.60 & 0 & 0 & 2.11 & 0.92 & 0 & 0.61 \\
\hline CYR20 & 4.60 & 1.36 & 0 & 9.47 & 1.84 & 0 & 2.53 \\
\hline CYR21 & 0.77 & 0 & 0 & 0 & 0.31 & 0 & 0.06 \\
\hline CYR22 & 0.38 & 0.68 & 0 & 0 & 0 & 0 & 0.14 \\
\hline CYR23 & 3.83 & 0 & 0 & 0 & 0.92 & 0 & 0.18 \\
\hline \multicolumn{8}{|l|}{ Lov10 group } \\
\hline CYR28 & 0 & 0.68 & 0 & 0 & 0 & 0 & 0.14 \\
\hline \multicolumn{8}{|l|}{ Lov13 group } \\
\hline CYR29 & 1.15 & 0.68 & 0 & 1.05 & 0 & 0.40 & 0.43 \\
\hline Lov-3 & 0 & 0.68 & 1.79 & 0 & 0.31 & 0 & 0.56 \\
\hline Lov-6 & 0.38 & 0 & 0 & 0 & 0.92 & 0 & 0.18 \\
\hline Lov-8 & 0 & 0 & 0 & 0 & 0.61 & 0 & 0.12 \\
\hline \multicolumn{8}{|l|}{ Hybrid 46 group } \\
\hline CYR31 & 5.36 & 3.40 & 0 & 2.11 & 0.61 & 1.61 & 1.55 \\
\hline CYR32 & 31.80 & 14.29 & 5.36 & 33.68 & 15.64 & 33.06 & 20.41 \\
\hline Hy46-4 & 0 & 1.36 & 0 & 0 & 0.31 & 0 & 0.33 \\
\hline Нy46-6 & 0 & 8.16 & 0 & 7.37 & 0.31 & 0.81 & 3.33 \\
\hline Hy $46-7$ & 0 & 0.68 & 0 & 3.16 & 0 & 0 & 0.77 \\
\hline Hy46-8 & 0 & 6.80 & 0 & 11.58 & 0.92 & 0.81 & 4.02 \\
\hline Нy46-9 & 0 & 0.68 & 0 & 0 & 0 & 0 & 0.14 \\
\hline \multicolumn{8}{|l|}{ Suwon 11 group } \\
\hline Su11-1 & 4.60 & 0.68 & 0 & 0 & 0 & 1.21 & 0.38 \\
\hline Su11-2 & 0.38 & 0 & 0 & 0 & 0.61 & 0.81 & 0.28 \\
\hline Su11-3 & 0.38 & 1.36 & 0 & 0 & 0.92 & 1.21 & 0.70 \\
\hline Su11-4 & 1.92 & 5.44 & 7.14 & 0 & 4.91 & 4.03 & 4.30 \\
\hline Su11-5 & 2.30 & 6.12 & 8.93 & 0 & 6.13 & 1.21 & 4.48 \\
\hline Su11-6 & 6.90 & 14.97 & 0 & 0 & 0.61 & 0 & 3.12 \\
\hline Su11-7 & 0.38 & 0 & 0 & 0 & 2.15 & 2.01 & 0.83 \\
\hline Su11-8 & 0.38 & 0 & 0 & 0 & 0 & 0.81 & 0.16 \\
\hline Su11-10 & 0 & 1.36 & 0 & 1.05 & 0.31 & 0 & 0.54 \\
\hline Su11-11 & 0 & 4.76 & 0 & 0 & 0 & 0.81 & 1.11 \\
\hline Su11-12 & 0 & 0.68 & 0 & 0 & 0 & 0 & 0.14 \\
\hline Su11-13 & 0.77 & 0.68 & 5.38 & 0 & 0.61 & 1.21 & 1.58 \\
\hline CYR33 & 24.14 & 7.48 & 48.21 & 7.37 & 20.55 & 40.73 & 24.87 \\
\hline Others & 4.98 & 17.01 & 23.21 & 21.05 & 39.57 & 9.27 & 22.02 \\
\hline Number of samples & 261 & 147 & 56 & 95 & 326 & 248 & $\ldots$ \\
\hline Number of races & 19 & 22 & 6 & 10 & 21 & 15 & $30^{\mathrm{a}}$ \\
\hline
\end{tabular}

a Number of races identified in all regions. 
Tibet carry additional virulence factors which may not be identified by the currently used differential genotypes; these complex virulence types may be sustained by local cultivars or wild Hordeum plants in Tibet.

This study indicated the possibility of Tibet as another center of P. striiformis f. sp. tritici diversity. If confirmed, it may have significant implications on stripe rust management, including cultivar deployment. Further research is needed to assess this possibility. In particular, further molecular studies are needed to assess differences among $P$. striiformis $\mathrm{f}$. sp. tritici populations from Tibet, Sichuan, and Gansu at several key time points in the epidemic within a season. Field-based monitoring of spatiotemporal dynamics of $P$. striiformis f. sp. tritici development, including volunteer wheat plants and alternative hosts during the oversummer and overwinter period, and modeling studies should be undertaken to assess the feasibility of large-distance dispersal of P. striiformis f. sp. tritici between Sichuan and Tibet within a growing season. Finally, efforts should be made to identify the genetic basis of the current wheat cultivars in Tibet, including minor local cultivars and wild Hordeum spp., against different $P$. striiformis f. sp. tritici races. Through these studies, we may gain better understanding of $P$. striiformis f. sp. tritici epidemiology and $P$. striiformis f. sp. tritici-host co-evolution for effective management of this disease.

\section{Acknowledgments}

The study was supported by the 111 project from Education Ministry of China (number B07049), the Agriculture Scheme Project (number 200903035), and the National Natural Science Foundation of China (numbers 31071640, 31071652, and 30960214).

\section{Literature Cited}

1. Chen, W. Q., Wu, L. R., Liu, T. G., Xu, S. C., Jin, S. L., Peng, Y. L., and Wang, B. T. 2009. Race dynamics, diversity, and virulence evolution in Puccinia striiformis $\mathrm{f}$. sp. tritici, the causal agent of wheat stripe rust in China from 2003 to 2007. Plant Dis. 93:1093-1101.

2. Chen, X. M. 2005. Epidemiology and control of stripe rust (Puccinia striiformis f. sp. tritici) on wheat. Can. J. Plant Pathol. 27:314-337.

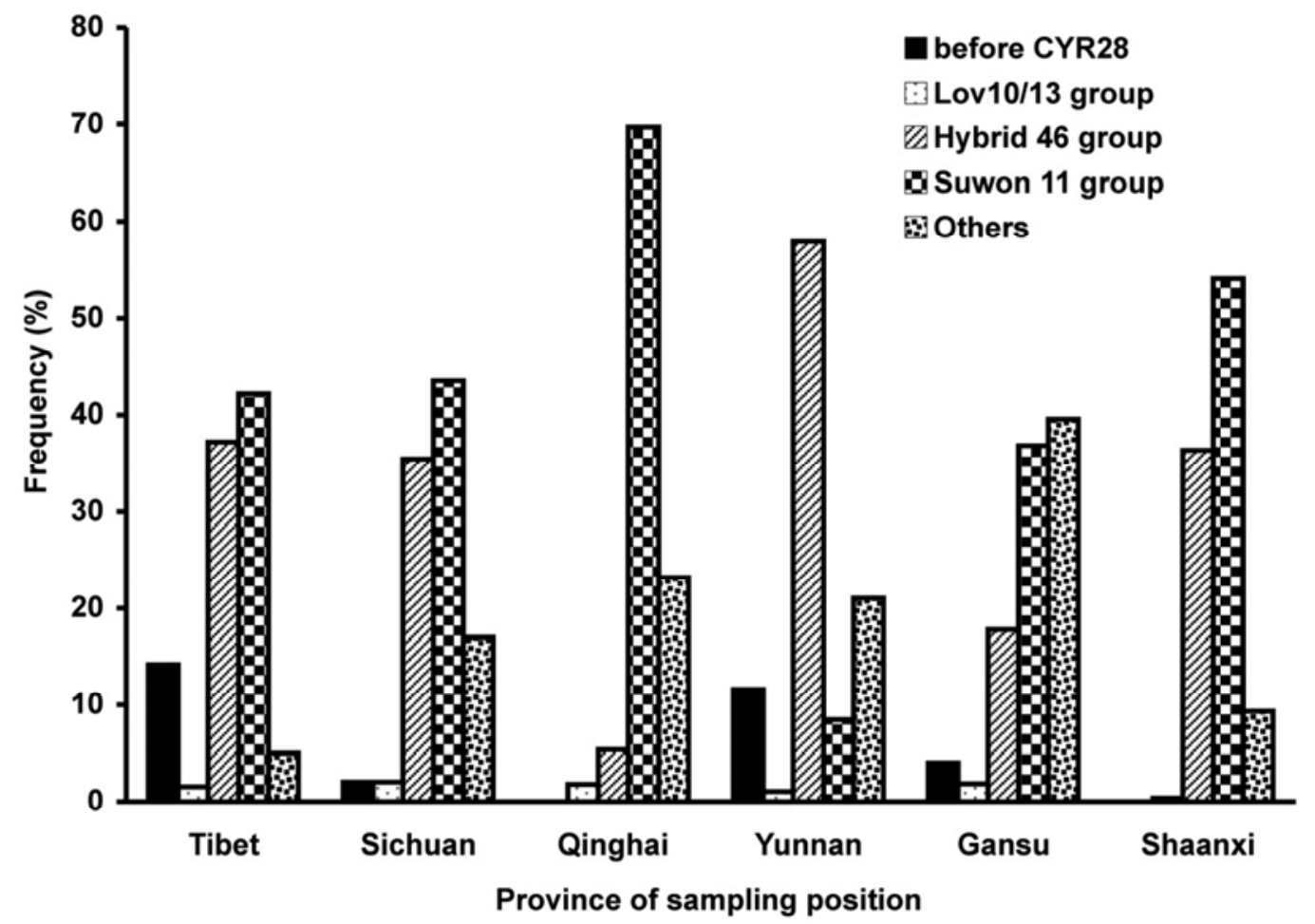

Fig. 2. Frequency of major races or race groups of Puccinia striiformis f. sp. tritici in the six central western regions of China in 2010.

Table 4. Frequencies of Puccinia striiformis f. sp. tritici races that overcame a number of selected host resistance genes in the six provinces of China in 2010

\begin{tabular}{|c|c|c|c|c|c|c|}
\hline \multirow[b]{2}{*}{ Host resistance genes (host) } & \multicolumn{6}{|c|}{ Province } \\
\hline & Tibet & Sichuan & Yunnan & Qinghai & Gansu & Shaanxi \\
\hline Yrl (Fengchan 3) & 95.16 & 99.18 & 100.00 & 100.00 & 100.00 & 98.67 \\
\hline Yr3 (Danish) & 85.48 & 97.54 & 96.00 & 100.00 & 95.43 & 98.67 \\
\hline Yr6 (Trigo Eureka) & 95.16 & 95.08 & 86.67 & 100.00 & 94.68 & 49.33 \\
\hline $\operatorname{Yr} 9($ Lovrin 13) & 70.97 & 55.74 & 26.67 & 100.00 & 87.31 & 94.22 \\
\hline Yr3b/4b (Hybrid46) & 39.11 & 42.62 & 73.33 & 27.91 & 29.44 & 38.22 \\
\hline $\operatorname{YrA}$ (Funo) & 90.32 & 99.18 & 100.00 & 100.00 & 98.48 & 98.67 \\
\hline YrVir1,2 (Virgilio) & 74.60 & 71.31 & 85.33 & 83.72 & 83.25 & 92.00 \\
\hline YrJu1,2,3,4 (Jubilejina) & 71.37 & 85.25 & 94.67 & 88.37 & 80.20 & 93.33 \\
\hline YrKy 1,2 (Kangyin) & 62.90 & 66.39 & 82.67 & 81.40 & 74.11 & 91.11 \\
\hline YrSu (Suwon11) & 84.27 & 96.72 & 85.33 & 100.00 & 93.40 & 99.56 \\
\hline Unknown (Fulhard) & 100.00 & 100.00 & 100.00 & 100.00 & 100.00 & 100.00 \\
\hline Unknown (Lutescenes 128) & 89.96 & 97.54 & 97.33 & 100.00 & 95.43 & 98.67 \\
\hline Unknown (Mentana) & 87.55 & 79.51 & 97.33 & 100.00 & 95.94 & 98.67 \\
\hline Unknown (Abbondanza) & 94.78 & 97.54 & 97.33 & 100.00 & 96.95 & 98.67 \\
\hline Unknown (Early Piemium) & 95.18 & 98.36 & 97.33 & 100.00 & 96.95 & 100.00 \\
\hline Unknown (Zhong 4) & 0 & 0 & 0 & 0 & 0 & 0 \\
\hline Unknown (Guinong 22) & 0 & 0 & 0 & 0 & 0 & 0 \\
\hline
\end{tabular}


3. Kang, Z. S., Li, Z. Q., Shang, H. S., Lu, H. P., and Liu, X. D. 1994. Discovery of new isolates virulent to wheat cultivars of Mianyang system in wheat stripe rust. Acta Univ. Agric. Boreali-occidentalis 22:7-11. (In Chinese with English abstract.)

4. Li, Z. Q., Wang, M. N., Jia, M. G., Lu, H. P., Shang, H. S., Kang, Z. S., Yang, S. F., Sun, S. M., and Shi, Y. C. 1997. Study of the epidemiology and control strategy of wheat stripe rust in South Gansu. Acta Univ. Agric. Boreali-occidentalis. 25:1-5. (In Chinese with English abstract)

5. Li, Z. Q., and Zeng, S. M. 2002. Pages 1-11 in: Wheat Rust in China. China Agricultural Press, Beijing. (In Chinese)

6. Line, R. F. 2002. Stripe rust of wheat and barley in North America: a retrospective historical review. Annu. Rev. Phytopathol. 40:75-118.

7. Line, R. F., and Chen, X. M. 1995. Successes in breeding for managing durable resistance to wheat rust. Plant Dis. 79:1254-1255.

8. Line, R. F., and Qayoum, A. 1991. Virulence, aggressiveness, evolution, and distribution of races of Puccinia striiformis (the cause of stripe rust of wheat) in North America, 1968-1987. U. S. Dep. Agric. Agric. Res. Serv. Tech. Bull. 1788 .

9. Liu, T. B., Wang, B. T., Jia, Q. Z., Zhang, Z. Y., Li Q., Cai, S. Q., Peng, Y. L., Jin, S. L., Li, M. J., Liu, B., Gao, L., Hu, X. P., and Chen, W. Q. 2012.Physiologic specialization of Puccinia striiformis f. sp. tritici in China during 2010-2011. J. Triticeae Crops. 32:574-578. (In Chinese with English abstract)

10. McIntosh, R. A., and Brown, G. N. 1997. Anticipatory breeding for resistance to rust diseases in wheat. Annu. Rev. Phytopathol. 35:311-326.

11. Stubbs, R. W. 1985. Stripe rust. Pages 61-101 in: The Cereal Rusts, Vol. II. A. P. Roelfs and W. R. Bushnell, eds. Academic Press, New York.

12. Wan, A. M., Zhao, Z. H., Chen, X. M., He, Z. H., Jin, S. L., Jia, Q. Z., Yao, G., Wang, B. T., Li, G. B., Bi, Y. Q., and Yuan, Z. Y. 2004. Wheat stripe rust epidemic and virulence of Puccinia striiformis f. sp. tritici in China in 2002. Plant Dis. 88:896-904.

13. Wang, B. T., Hu, X. P., Li, Q., Hao, B. J., Zhang, B., Li, G. B., and Kang, Z.
S. 2010. Development of race-specific SCAR markers for detection of Chinese races CYR32 and CYR33 of Puccinia striiformis f. sp. tritici. Plant Dis. 94:221-228.

14. Wang, K. N., Hong, X. W., Wu, L. R., Xie, S. X., Meng, Q. Y., and Chen, S. M. 1986. The analysis of the resistance of varieties in the wheat stripe rust nurseries on 1951-1983. J. Plant Prot. 13:117-124. (In Chinese with English abstract)

15. Wang, K. N., Xie, S. X., Liu, X. K., Wu, L. R., Wang, J. X., and Chen, Y. L. 1988. Progress in studies on control of wheat stripe rust in China. Sci. Agric. Sin. 16:80-85. (In Chinese with English abstract)

16. Wang, Z. H. 1992. Regional epidemics of stripe rust on barley and wheat in Tibet. Southwest China J. Agric. Sci. 5:79-85. (In Chinese with English abstract)

17. Wang Z. H. 1992. Oversummering and overwintering of Puccinia striiformis West. in Tibet. Southwest China J. Agric. Sci. 5:64-68. (In Chinese with English abstract)

18. Wang, Z. H., Peng, Y. L., Lamu, Y. J., and Dazhen. 1989. Difference of pathogenicity between isolates of barley-attacking and wheat-attacking forms of Puccinia striiformis with special reference to the deviation of disease development. Acta Phytopathol. Sin. 19:161-165. (In Chinese with English abstract)

19. Wang, Z. H., and Wang, M. 1992. Analysis on variability of resistance to wheat stripe rust of varieties in nurseries in Tibet on 1986-1992. Southwest China J. Agric. Sci. 5:88-93. (In Chinese with English abstract)

20. Wellings, C. R. 2007. Puccinia striiformis in Australia: a review of the incursion, evolution, and adaptation of stripe rust in the period 1979-2006. Aust. J. Agric. Res. 58:567-575.

21. Wellings, C. R, and McIntosh, R. A. 1990. Puccinia striiformis f. sp. tritici in Australasia: Pathogenic changes during the first ten years. Plant Pathol. 39:316-325

22. Wu, L. R., and Niu, Y. C. 2000. Strategies of sustainable control of wheat stripe rust in China. Sci. Agric. Sin. 33:1-7. 